\title{
Effect of Deficit Irrigation on Physico-chemical Characteristics in Various Kiwifruit (Actinidia deliciosa Chev.) Cultivars
}

\author{
Preet Pratima*, N. Sharma and Heerendra Sagar
}

Dept. of Fruit Science, College of Horticulture, Dr. Y. S. P. University of Horticulture and Forestry, Nauni, Solan, HP (173 230), India

\section{Corresponding Author}

Preet Pratima

e-mail: preetepitome@gmail.com

\author{
Article History \\ Article ID: AR1851 \\ Received in 29 ${ }^{\text {th }}$ November, 2017 \\ Received in revised form $16^{\text {th }}$ February, 2018 \\ Accepted in final form 25 $5^{\text {th }}$ March, 2018
}

\begin{abstract}
The kiwifruit vines probably die more often because of water stress than any other problems. There is a need to screen out such cultivars which have potential to grow in water scarce areas. With this objective, the present investigation was carried out in the experimental area of Department of Fruit Science, Dr. Y. S. Parmar University of Horticulture and Forestry Nauni during 2011-2012. Two irrigation levels viz., Irrigation at $80 \%$ field capacity (standard irrigation-SI) and irrigation at $60 \%$ FC (deficit irrigation-DI) with four replications were given in five cultivars viz., Allison, Hayward, Abbott, Monty and Bruno. The experiment was arranged in Randomized Block Design. The fruit quality characteristics were significantly variable among the cultivars and were also influenced by the irrigation levels. Under SI the fruit quality in terms of fruit weight, firmness and ascorbic acid content was found to be highest in cultivar Bruno among all these mentioned cultivars whereas, the titratable acidity under SI was found to be highest in cultivar Monty and least in Allison. The DI resulted in reduction in all these attributes and the percent reduction is found to be highest in cultivar Hayward and least in Bruno. The parameters like total soluble solids (TSS) and sugars were found to be highest in cultivar Allison and least in Monty under SI but the percent increase in these characteristics were found to be highest in cultivar Hayward and least in cultivar Bruno. The Bruno cultivar was found to be suitable under deficit irrigation and therefore, it should be preferred for cultivation under water scarce areas.
\end{abstract}

Keywords: Kiwifruit, deficit irrigation, physicochemical characteristics, sugars, ascorbic acid

\section{Introduction}

The kiwifruit or Chinese gooseberry (Actinidia deliciosa Chev.) is a deciduous fruit vine, native to Yangtze valley of south and central China (Ferguson, 1984). The fruit has an excellent table and keeping quality and acclaimed for its nutritive and medicinal values. Kiwifruit is a rich source of vitamin $\mathrm{C}$, vitamin $\mathrm{K}$, and vitamin $\mathrm{E}$ and provides dietary fiber and minerals like $\mathrm{P}, \mathrm{K}$ and $\mathrm{Ca}$. In India, therefore it can be grown successfully in areas situated at elevation of 900 to $1800 \mathrm{~m}$ above mean sea level where, the winters are cold and summers are warm and humid, and receive well distributed annual rainfall of about $150 \mathrm{~cm}$. A deep friable well-drained sandy loam to clay soil coupled with assured irrigation is the best ideal condition for growing kiwifruit. In water scarce areas where the kiwifruit plants cannot fulfill their water requirement which resulted in reduction in fruit set, fruit growth and fruit size which ultimately leads to reduction in the overall production of kiwifruit (Beutel, 1990). Water deficit typically reduce yield, particularly if a deficit occurs early in the growing season, when the inflorescences are not competitive in comparison with the shoot tips (Williams and Matthews, 1990).
Inadequate water supply before bloom can lead to abortion of entire inflorescences (limiting cluster number), stress during bloom results in poor fruit set (limiting berry number), and stress during the early stages of fruit development restricts berry growth (limiting berry size). The cell division is much less sensitive to changes in water status than in cell expansion (Ojeda, 2001). This effect is particularly severe if vines are drought stressed early in the growing season when fruit are in their most rapid phase of expansion. If the water is limiting during the early fruit growth, any reduction in fruit size is irreversible (Janick, 2008). Consequently, there should be an ample opportunity for early season environmental factors to influence berry size (Coombe, 1976; Keller, 2010). As the cell division depend on carbon supply, the stress factors diminish the supply of assimilates and limit the cell number and hence berry size (Caspari, 1998; Van Volkenburgh, 1999).The early stress leads to fewer seeds per berry and strongly reduces the size of mesocarp cells but does not impair fruit ripening (Ollat, 2002). The later stress limit only cell expansion which may result in somewhat smaller berries. In vineyards, it has been claimed that partial root drying helps in controlling excessive vegetative growth and improves grape quality while 
not reducing fruit production (Loveys et al., 2000). Kiwifruit vines probably die more often from some type of water stress than any other problems. The limited supply of irrigation during summer resulted in significant reduction in harvest weight. Thus, there is a need to screen out such cultivars which have potential to grow in water scarce areas and with this objective; the present investigation was carried out. The knowledge of adaptability of kiwifruit cultivars to water deficit regions in terms of fruit quality attributes, it might proved to be beneficial information to the kiwifruit growers to prefer suitable kiwifruit cultivar for cultivation in their region.

\section{Materials and methods}

The present research was conducted in the Department of Fruit Science, Dr. Y. S. Parmar University of Horticulture and Forestry, Solan, HP, India, during the years 2011 and 2012. The twenty five-year-old uniform vines of five different kiwifruit cultivars viz., Allison, Abbott, Monty, Hayward and Bruno were selected for this investigation. The vines of these cultivars were planted at $6 \times 4 \mathrm{~m}^{2}$ spacing and trained on T-bar system. These vines were subjected to two irrigation levels viz., $\mathrm{T}_{1}$ - irrigation at $80 \%$ Field Capacity $(\mathrm{FC})$ and $\mathrm{T}_{2}$ - irrigation at $60 \%$ FC with four replications, in Randomized Block Design. These irrigation treatments were applied to vines from March to October. The fruit samples for physico-chemical analysis were collected when the fruits had attained full maturity. Ten fruits were collected randomly from all sides of the vines and then they were brought to the laboratory in polythene bags for physico-chemical analysis. The various fruit quality parameters were observed by following the procedure mentioned below:

\subsection{Fruit size}

The fruit size was measured in terms of length and diameter. The length and diameter of ten randomly selected fruits per vine were measured at the time of harvest with Digimatic caliper. The average fruit length and diameter were calculated and expressed in $\mathrm{mm}$.

\subsection{Fruit weight}

The fruit weight was recorded by selecting ten fruits on a top pan balance and the average weight was expressed in gram per fruit.

\subsection{Titratable acidity}

For estimating titrable acidity, $25 \mathrm{~g}$ of fruit pulp was thoroughly mixed with distilled water in an electric blender and the volume was made to $250 \mathrm{ml}$. The mixture was then filtered through Whatman No. 1 filter paper and $50 \mathrm{ml}$ of sample was then titrated against $\mathrm{N} / 10 \mathrm{NaOH}$ solution using phenolphthalein as an indicator till it gave pink coloured end point. The total titratable acidity was calculated in terms of citric acid on the basis of $1 \mathrm{ml}$ of $\mathrm{N} / 10 \mathrm{NaOH}$ equivalent to $0.0067 \mathrm{~g}$ of anhydrous citric acid and expressed as percent citric acid in juice (Ranganna, 1995). The remaining filtered solution was used for sugar estimation.

\subsection{Ascorbic acid}

The quantitative determination of ascorbic acid was done with the help of indophenols solution (2,6 dichlorophenol indophenols dye). Indophenol dye solution was first standardized against standard ascorbic acid. The indophenols dye and metaphosphoric acid solution were prepared fresh for each set of experiment and standardized against standard ascorbic acid to calculate the dye factor (AOAC, 1980). Ten grams of fruit pulp was homogenized in 3\% metaphosphoric acid solution and volume was made up to $50 \mathrm{ml}$ in volumetric flask. This solution was titrated against indophenols dye. The end point was determined by the appearance of rose pink colour which persisted for few seconds. The amount of ascorbic acid in milligram per hundred grams of fresh fruit pulp was calculated by using following formula:

Dye factor $\times$ Titre reading $\times$

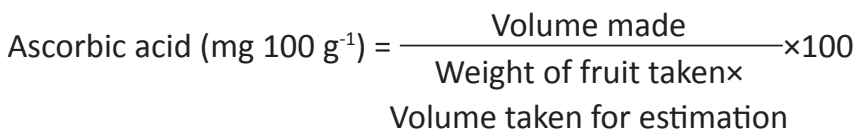

\subsection{Fruit firmness}

At the time of harvesting the fruit firmness was observed with a pressure tester (Effegi penetrometer) which recorded the pressure necessary for the plunger to penetrate the peeled flesh of kiwifruit and expressed in term of $\mathrm{kg} / \mathrm{cm}^{2}$.

\subsection{Total soluble solids (TSS)}

The TSS content was determined with Erma-hand refractrometer ( 0 to $32^{\circ} \mathrm{B}$ ). The refractrometer was calibrated with distilled water before use. The total soluble solids were expressed in ${ }^{\circ}$ Brix.

\section{7. Total sugars}

To the remaining $200 \mathrm{ml}$ filtered stock solution (left from titratable acidity), $10 \mathrm{ml}$ of $45 \%$ saturated lead acetate was added, contents of flask were shaken and filtered. Ten $\mathrm{ml}$ of $22 \%$ potassium oxalate was later added to precipitate the excess of lead and the contents were again filtered and volume was made to $250 \mathrm{ml}$. Out of this, $100 \mathrm{ml}$ of filtrate was taken in $250 \mathrm{ml}$ volumetric flask and $5 \mathrm{ml}$ concentrated $\mathrm{HCl}$ was added to it and left over night for hydrolysis at room temperature.

\subsection{Reducing sugars}

The remaining unhydrolyzed, deleaded and clarified solution obtained from the total sugar estimation was titrated against a boiling solution of $5 \mathrm{ml}$ each of Fehling $A$ and Fehling B using methylene blue as an indicator (Ranganna, 1995). Reducing sugars content was expressed as percentage of fresh pulp weight.

\subsection{Non-reducing sugar}

The amount of non-reducing sugar was calculated by subtracting the reducing sugars from the total sugars and multiplying the difference by a standard factor i.e. 0.95. The results were expressed as percent non-reducing sugars.

The statistical analysis of the data was carried out as per 
method described by Gomez and Gomez (1984). The significance of different treatment's effect was tested at $5 \%$ level of significance as suggested by Cochran and Cox (1963).

\section{Results and Discussion}

The fruit size viz., length and diameter (Plate 1), fruit weight, titratable acidity and ascorbic acid content were significantly influenced by different irrigation levels during both the years of study (Table 1). All these attributes decreased with deficit irrigation treatment and the percent reduction in these attributes is presented in Figure 1. The fruit length, fruit diameter, fruit weight, titratable acidity and ascorbic acid content of kiwifruit

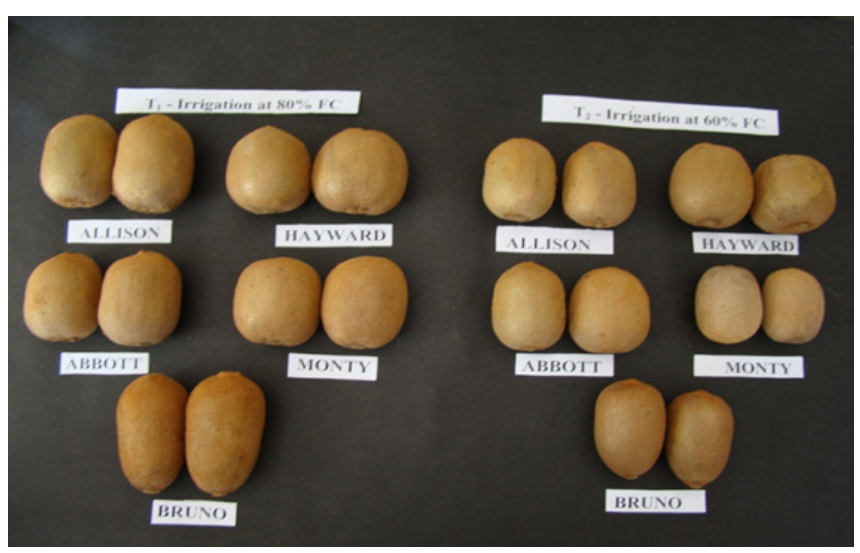

Plate 1: Effect of irrigation levels on fruit size of different kiwifruit cultivars cultivars decreased following the deficit irrigation treatment compared with control. The cultivars also showed significant variations in these attributes under different water regimes during both the years of study. The interaction effect of cultivars and irrigation levels on fruit length, fruit diameter, fruit weight, titratable acidity and ascorbic acid content were also significant.

Figure 1 showed that the percent decrease in fruit length due to deficit irrigation was greater in cultivar Hayward $(7.72 \%$ decrease over the control), while the decrease in fruit length

Physicochemical parameters of kiwifruit cultivars

Allison $\square$ Hayward $\square$ Abbott $\square$ Monty $\square$ Bruno

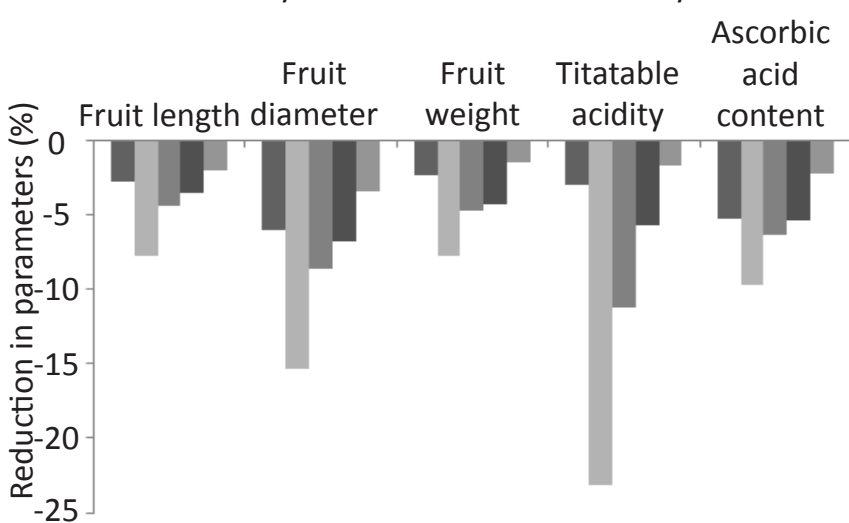

Figure 1: Per cent reduction in various physicochemical parameters of different cultivars of kiwifruit at irrigation at $60 \%$ FC over $80 \%$ FC

\begin{tabular}{|c|c|c|c|c|c|c|c|c|c|c|}
\hline \multirow[t]{2}{*}{ Cultivars } & \multicolumn{2}{|c|}{ Fruit length (mm) } & \multicolumn{2}{|c|}{$\begin{array}{l}\text { Fruit diameter } \\
(\mathrm{mm})\end{array}$} & \multicolumn{2}{|c|}{ Fruit weight (g) } & \multicolumn{2}{|c|}{$\begin{array}{l}\text { Fruit firmness } \\
\qquad\left(\mathrm{kg} \mathrm{cm}^{-2}\right)\end{array}$} & \multicolumn{2}{|c|}{ TSS ( $\left.{ }^{\circ} \mathrm{B}\right)$} \\
\hline & SI & DI & SI & $\mathrm{DI}$ & SI & DI & SI & $\mathrm{DI}$ & SI & DI \\
\hline Allison & 78.5 & 76.3 & 45.3 & 42.6 & 88.0 & 85.9 & 5.31 & 5.64 & 15.7 & 16.9 \\
\hline Hayward & 71.3 & 65.8 & 53.6 & 45.4 & 84.4 & 77.9 & 5.47 & 6.00 & 15.3 & 18.3 \\
\hline Abbott & 74.0 & 70.8 & 42.5 & 38.8 & 85.4 & 81.4 & 5.53 & 5.94 & 14.0 & 16.4 \\
\hline Monty & 73.2 & 70.6 & 46.1 & 43.0 & 82.9 & 79.4 & 5.03 & 5.39 & 13.6 & 15.2 \\
\hline Bruno & 92.2 & 90.3 & 40.9 & 39.5 & 88.5 & 87.2 & 6.68 & 6.78 & 14.2 & 15.1 \\
\hline Mean & 77.8 & 74.7 & 45.7 & 41.8 & 85.8 & 82.3 & 5.60 & 5.95 & 14.5 & 16.4 \\
\hline \multicolumn{11}{|l|}{$\operatorname{CD}(p=0.05)$} \\
\hline Irrigation treatments (I) & \multicolumn{2}{|c|}{0.1} & \multicolumn{2}{|c|}{0.1} & \multicolumn{2}{|c|}{0.1} & \multicolumn{2}{|c|}{0.01} & \multicolumn{2}{|c|}{0.1} \\
\hline Cultivars (C) & \multicolumn{2}{|c|}{0.1} & \multicolumn{2}{|c|}{0.1} & \multicolumn{2}{|c|}{0.1} & \multicolumn{2}{|c|}{0.01} & \multicolumn{2}{|c|}{0.1} \\
\hline $\begin{array}{l}\text { Irrigation treatmentsx } \\
\text { Cultivars }(I \times C)\end{array}$ & \multicolumn{2}{|c|}{0.1} & \multicolumn{2}{|c|}{0.1} & \multicolumn{2}{|c|}{0.2} & \multicolumn{2}{|c|}{0.02} & \multicolumn{2}{|c|}{0.1} \\
\hline \multicolumn{11}{|l|}{ SEm \pm} \\
\hline Irrigation treatments (I) & \multicolumn{2}{|c|}{0.01} & \multicolumn{2}{|c|}{0.02} & \multicolumn{2}{|c|}{0.03} & \multicolumn{2}{|c|}{0.03} & \multicolumn{2}{|c|}{0.02} \\
\hline Cultivars (C) & \multicolumn{2}{|c|}{0.02} & \multicolumn{2}{|c|}{0.03} & \multicolumn{2}{|c|}{0.04} & \multicolumn{2}{|c|}{0.05} & \multicolumn{2}{|c|}{0.03} \\
\hline $\begin{array}{l}\text { Irrigation treatments } \times \\
\text { Cultivars }(\mid \times C)\end{array}$ & \multicolumn{2}{|c|}{0.03} & \multicolumn{2}{|c|}{0.05} & \multicolumn{2}{|c|}{0.06} & & & & \\
\hline
\end{tabular}


due to deficit irrigation was the least in cultivar Bruno (2.01\%), followed by the cultivar Allison. The percent decrease in fruit diameter due to deficit irrigation was highest in cultivar Hayward (15.3\%), and the least in cultivar Bruno (3.4\%). The percent reduction in the fruit weight due to deficit irrigation treatment was higher in cultivar Hayward $(7.76 \%)$ while the percent reduction in fruit weight was lower in cultivars Bruno (1.53\%). The percent reduction in the fruit titratable acidity following deficit irrigation treatment was more pronounced in cultivar Hayward (23.2\%), while the reduction in fruit titratable acidity due to deficit irrigation was the least in cultivar Bruno (1.7\%). The deficit irrigation caused higher percent decrease in ascorbic acid content in cultivar Hayward (9.77\%), while the decrease in fruit ascorbic acid content due to deficit irrigation was the least in cultivar Bruno (2.23\%).

The results revealed the fruit quality characteristics were significantly variable among the cultivars and were also influenced by the irrigation levels. The maximum fruit length and fruit diameter were observed in cultivars Bruno and Hayward, respectively. Conversely, vines of cultivars Bruno and Hayward produced fruits with minimum diameter and length, respectively. The fruit weight was found to be highest in cultivar Bruno followed by Allison and the least in cultivar Monty under well irrigated condition. The DI treatment resulted in significant retention in fruit size and fruit weight, however, the percent reduction in fruit size and weight due to DI was found to be highest in cultivar Hayward and the least in cultivar Bruno. It is well understood that variability in fruit size and weight of different cultivars are due to their hereditary characteristic; however these are likely to be altered by environmental conditions. Reduced fruit size and fruit weight as a result of water stress is well known and widely reported (Berman and Dejong, 1996). Water potential is highly correlated with plant relative water content (Koide et al., 1991), and the water stress vines having lower water potential than the well irrigated vines, would be expected to have reduced whole vine relative water content. In sufficient photosynthate supply due to inadequate leaf area or low rates of photosynthesis limits both cell division and cell expansion, with very little compensation later in season so that final berry size is irreversibly reduced. Therefore, berry size at harvest also tends to decline as the number of berries per vine increases (Keller et al., 2008). Prior to fruit set, the flowers have weak sink strength, but the developing seeds and berries are stronger sinks than shoots and roots. Therefore, although stress reduce seed and berry size, the decrease is less than would be expected from the reduction in photosynthetic availability. This is probably due to remobilization of stored reserves in both the leaves and the permanent parts of the vine (Keller, 2015). In the present study, lesser reduction in fruit size and weight in cultivar Bruno and Allison may be related to marginal decrease in leaf water potential, photosynthetic rate and RWC in these cultivar under water stress.
In this study, deficit irrigation resulted in decreased total titratable acidity and ascorbic acid contents of fruits in all the cultivars, which were however, more marked in cultivar Hayward, whereas cultivars Bruno and Allison remained less affected in respect of these fruit quality parameters. Peterlunger et al. (2002) also observed reduction in titratable acidity with water stress at harvest in Merlot grape vines grafted on $\mathrm{SO}_{4}$ rootstocks. A decrease in leaf ascorbic acid with drought stress has been reported in pear (Sharma and Sharma, 2009).

The fruit firmness, total soluble solids (TSS) content, fruit total sugars, reducing sugars and non reducing sugars contents were significantly influenced by different irrigation levels during both the years of study. All these attributes increased with deficit irrigation treatment and the percent increase in these attributes is presented in Figure 2. The fruit firmness, total soluble solids (TSS) content, fruit total sugars, reducing sugars and non reducing sugars contents of kiwifruit cultivars increased significantly following the application of deficit irrigation compared with standard irrigation practice (control) during the year 2011 and 2012 (Table 2). The cultivars also showed significant variations in these attributes under different water regimes during both the years of study. The interaction effect of cultivars and irrigation levels on fruit firmness, total soluble solids (TSS) content, fruit total sugars, reducing sugars and non reducing sugars contents were also significant.

It is apparent from the Figure 2 that the percent increase in fruit firmness caused by the deficit irrigation treatment was more in cultivar Hayward (9.60\%), while the increase in fruit firmness due to deficit irrigation was the least in cultivar Bruno (1.58\%). The percent increase in the fruit TSS due to deficit irrigation treatment was more in cultivar Hayward (19.6\% increase over the control), while the increase in fruit TSS was the least in cultivar Bruno (6.0\%). The percent increase in total sugars in fruits due to deficit irrigation treatment was more in cultivar Hayward (15.9\% increase over the control),

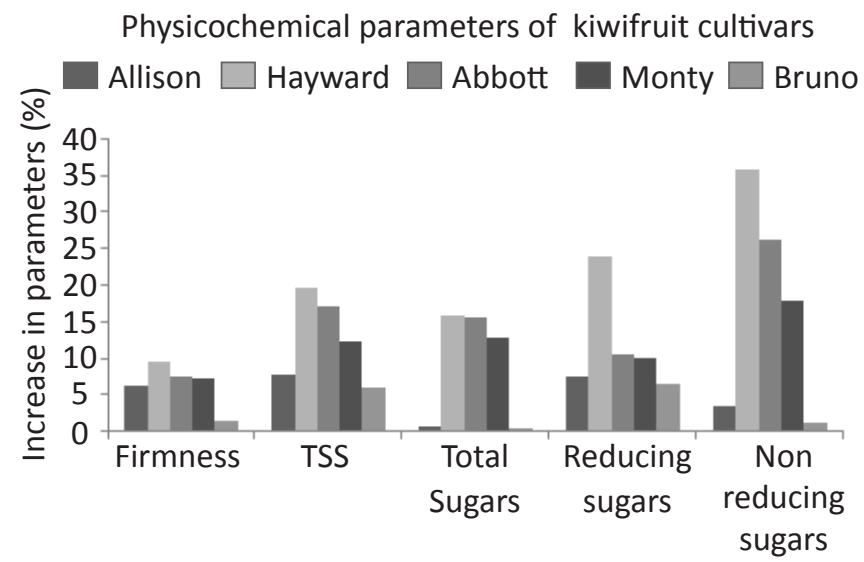

Figure 2: Per cent increase in various physicochemical parameters of different cultivars of kiwifruit at irrigation at $60 \%$ FC over $80 \%$ FC 


\begin{tabular}{|c|c|c|c|c|c|c|c|c|c|c|}
\hline \multirow[t]{2}{*}{ Cultivars } & \multicolumn{2}{|c|}{$\begin{array}{l}\text { Titratable } \\
\text { acidity (\%) }\end{array}$} & \multicolumn{2}{|c|}{$\begin{array}{c}\text { Total } \\
\text { sugars (\%) }\end{array}$} & \multicolumn{2}{|c|}{$\begin{array}{l}\text { Reducing } \\
\text { sugars (\%) }\end{array}$} & \multicolumn{2}{|c|}{$\begin{array}{l}\text { Non-reducing } \\
\text { sugas (\%) }\end{array}$} & \multicolumn{2}{|c|}{ 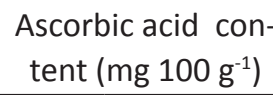 } \\
\hline & SI & DI & SI & DI & SI & DI & SI & DI & SI & DI \\
\hline Allison & 1.18 & 1.14 & 9.20 & 9.27 & 6.09 & 6.54 & 2.25 & 2.33 & 78.4 & 74.2 \\
\hline Hayward & 1.19 & 0.91 & 9.06 & 10.50 & 6.82 & 8.45 & 2.13 & 2.90 & 86.0 & 77.6 \\
\hline Abbott & 1.21 & 1.07 & 8.17 & 9.44 & 5.53 & 6.11 & 2.51 & 3.17 & 83.9 & 78.6 \\
\hline Monty & 1.24 & 1.17 & 8.09 & 9.13 & 5.17 & 5.69 & 2.77 & 3.27 & 87.9 & 83.1 \\
\hline Bruno & 1.22 & 1.20 & 8.14 & 8.17 & 5.73 & 6.10 & 2.29 & 2.31 & 91.9 & 89.9 \\
\hline Mean & 1.20 & 1.10 & 8.53 & 9.30 & 5.87 & 6.58 & 2.39 & 2.79 & 85.6 & 80.7 \\
\hline \multicolumn{11}{|l|}{$\operatorname{CD}(p=0.05)$} \\
\hline Irrigation treatments (I) & \multicolumn{2}{|c|}{0.01} & \multicolumn{2}{|c|}{0.01} & \multicolumn{2}{|c|}{0.01} & \multicolumn{2}{|c|}{0.01} & \multicolumn{2}{|r|}{0.1} \\
\hline Cultivars (C) & \multicolumn{2}{|c|}{0.01} & \multicolumn{2}{|c|}{0.02} & \multicolumn{2}{|c|}{0.01} & \multicolumn{2}{|c|}{0.01} & \multicolumn{2}{|r|}{0.2} \\
\hline $\begin{array}{l}\text { Irrigation treatmentsxcul- } \\
\text { tivars }(I \times C)\end{array}$ & \multicolumn{2}{|c|}{0.01} & \multicolumn{2}{|c|}{0.02} & \multicolumn{2}{|c|}{0.01} & \multicolumn{2}{|c|}{0.02} & \multicolumn{2}{|r|}{0.2} \\
\hline \multicolumn{11}{|l|}{ SEm \pm} \\
\hline Irrigation treatments (I) & \multicolumn{2}{|c|}{0.01} & \multicolumn{2}{|r|}{0.03} & \multicolumn{2}{|c|}{0.01} & \multicolumn{2}{|c|}{0.03} & \multicolumn{2}{|r|}{0.04} \\
\hline Cultivars (C) & \multicolumn{2}{|c|}{0.02} & \multicolumn{2}{|r|}{0.06} & \multicolumn{2}{|c|}{0.02} & \multicolumn{2}{|c|}{0.04} & \multicolumn{2}{|r|}{0.06} \\
\hline $\begin{array}{l}\text { Irrigation treatments } \times \\
\text { cultivars }(I \times C)\end{array}$ & \multicolumn{2}{|c|}{0.03} & \multicolumn{2}{|r|}{0.08} & \multicolumn{2}{|c|}{0.03} & & & & 0.08 \\
\hline
\end{tabular}

and the least in cultivar Bruno (0.4\%). The percent increase in fruit reducing sugar content (Figure 2) due to deficit irrigation treatment was highest in cultivar Hayward (24.0\%) and the lowest in cultivar Bruno (6.4\%). The deficit irrigation treatment caused a higher $\%$ increase in the non reducing sugars in cultivar Hayward (35.9\% increase over control), conversely, the increase in non-reducing sugars was the least in cultivar Bruno (1.1\%).

These results clearly indicated that fruit were more firm with higher soluble solids and sugar contents from vines subjected water stress in all the cultivars. However, the increase in these attributes due to water stress was more pronounced in cultivar Hayward and the least in cultivar Bruno. Fruit size has somewhat inverse correlation with fruit firmness, fruit TSS and sugar contents. A mild drought stress during early fruit growth can result in beneficial effects on the post-harvest storage characteristics as fruits from non-irrigated vines were firmer and stored better than fruit from irrigated vines (Reid et al., 1996; Ruiz-Sanchez, et al., 2010). Increased fruit firmness due to water stress may be due to the low Ca level in leaves and high Ca levels in berries, as the Ca plays important role in enhancing the berry skin thickness (Porro et al., 2010).

\section{Conclusion}

The fruit quality attributes viz., fruit size, fruit weight, titratable acidity and ascorbic acid content of kiwifruit cultivars were found to be higher under standard irrigation regime and these declined significantly under deficit irrigation treatment. Whereas, the fruit quality attributes viz., fruit firmness, TSS content, fruit sugars, were increased by applying deficit irrigation treatment. The kiwifruit cultivar Bruno exhibits marked performance in terms of all these fruit quality attributes under deficit irrigation followed by cultivar Allison. Thus, the cultivar Bruno should be preferred for cultivation under water scarce areas.

\section{Acknowledgement}

Authors are very thankful to Dr. Y.S. Parmar University of Horticulture and Forestry, Nauni, Solan (H. P.), India for providing financial assistance and all the facilities for the study.

\section{References}

AOAC, 1980., Official Methods of Analysis of the Analytical Chemists (13 ${ }^{\text {th }}$ Edn.). Horowitz, W. (Ed.). Association of official Analytical Chemists, Benjamin Franklin Station, Washington, D.C., 1018.

Berman, M. E., De Jong, T.M., 1996. Water stress and crop load effects on fruit fresh and dry weights in peach (Prunus persica). Tree Physiology 16, 859-864.

Beutel, J.A., 1990. Kiwifruit. In: Janick, J., Simon, J.E. (Eds.), Advances in new crops. Timber Press, Portland, OR, 309-316.

Caspari, H., Lang, A., Alspach, P., 1998. Effects of girdling and 
leaf removal on fruit set and vegetative growth in grape. American Journal of Enology and Viticulture 49, 359-366.

Cochran, G.C., Cox, G.M., 1963. Experimental Design, Asia Publishing House, Bombay, 611.

Coombe, B.G., 1976. The Development of Fleshy Fruits. Annual Review of Plant Physiology 27, 507-528.

Ferguson, A.R., 1984. Kiwifruit: a botanical review. Horticultural Reviews 6, 1-64.

Gomez, K.A., Gomez, A.A., 1984. Statistical Procedures for Agricultural Research, John Willey and Son, New York.

Janick, J., Paull, R.E., 2008. The Encyclopedia of Fruit and Nuts. In : Janick, J., Paull, R.E. (Eds.), Actinidiaceae. CAB International. Wallingford, UK ; Cambridge, MA: CABI North American Office,. Chicago, 1-7.

Keller, M., 2010. Managing grapevines to optimize fruit development in a challenging environment: A climate change primer for viticulturists. Australian Journal of Grape and Wine Research 16, 56-69.

Keller, M., 2015. The Science of Grape vines: Anatomy and Physiology. In: Developmental Physiology: Grape composition and Fruit Quality. Second edition, Elsevier Inc. The Boulevard, Langford Lane, Kidlington, Oxford OX5 IGB, UK, 205-236.

Keller, M., Smithyman, R.P., Mills, L.J., 2008. Interactive effects of deficit irrigation and crop load on Cabernet Sauvignon in an arid climate. American Journal of Enology and Viticulture 59, 221-234.

Koide, R.T., Robichaux, R.H., Morse, S.R., Smith, C.M., 1991. Plant water status, hydraulic resistance and capacitance. In: Pearcy, R.W., Ehleringer, J., Moony, H. A., Rundel, P.W., (Eds.), Plant Physiology Ecology. Chapman and Hall, London, 161-183.

Loveys, B.R., Dry, P.R., Stoll, M., McCarthy, M.G., 2000. Using plant physiology to improve the water efficiency of horticultural crops. Acta Horticulturae 537, 187-197.

Ojeda, H., Deloire, A., Carbonneau, A., 2001. Influence of water deficits on grape berry growth. Vitis 40(3), 141-145.

Ollat, N., Diakou, V. P., Carde, J.P., Barrieu, F., Gaudillere, J.P., Moing, A., 2002. Grape berry development: a review, Journal International des Sciences de la Vigne et du Vin 36, 109-131.

Peterlunger, E., Sivilotti, P., Bonetto, C., Paladin, M., 2002. Water stress induces changes in polyphenol concentration in Merlot grapes and wines. Rivista di Viticoltura e di Enologia 55(1), 51-66.

Porro, D., Ramponi, M., Tomasi, T., Rolle, L., Poni, S., 2010. Nutritional implications of water stress in grapevine and modifications of mechanical properties of berries. Acta Horticulturae 868, 73-80.

Ranganna, 1995. Handbook of analysis and quality control for fruits and vegetable production. Tata McGraw Hill Publishing Company Limited, New Delhi, 1-21.

Reid, J.B., Brash, D.W., Sorensen, I.B., Bycroft, B., 1996. Improvement in kiwifruit storage life caused by withholding early season irrigation. New Zealand Journal of Crop and Horticultural Science 24, 21-28.

Ruiz-Sanchez, M.C., Domingo, R., Castel, J.R., 2010. Review. Deficit irrigation in fruit trees and vines in Spain. Spanish Journal of Agricultural Research 8(S2), S5-S20.

Sharma, S., Sharma, N., 2009. Changes in leaf water potential, electrolyte linkage, antioxidant system and anatomical characteristics in Flemish Beauty pear as induced by paclobutrazol during water stress. Advances in Horticultural Science (Itlay) 23(1), 8-12.

Van, V.E., 1999. Leaf expansion- an integrating plant behavior. Plant, Cell and Environment 22, 1463-1473.

Williams, L. E., Matthews, M. A., 1990. Grapevine. In: Irrigation of Agricultural crops. Stewart, B.A., Nielsen, D.R. (Eds.), Agronomy Monograph No. 30. ASA-CSSA-SSSA, Madison, WI, 1019-1055. 